\title{
IN-SUBSTANCE DEFEASANCE OF DEBT: A SOLUTION TO A MANAGEMENT PROBLEM
}

\section{W. Alfred Mukatis \\ and Dahli Gray}

Department of Accounting

Oregon State University

Corvallis, Oregon

Defeasance of debt has been recognized for many years. In defeasance a debtor includes in the debt instrument the legal right to transfer the debt with assets adequate to meet the debt obligation to a trust. In this way the debt is extinguished without being retired. The creditor, holding the debt instrument, knows the debtor may set up a trust to extinguish the debt without retiring it. Benefits of defeasance to the debtor include: (1) no payment penalties for early debt retirement; (2) recognition of unrealized gain in the income statement, which enhances earnings per share (EPS) and other indicators of performance; and (3) removal of debt from the balance sheet, which enhances the debt-to-equity ratio and other indicators of financial strength. Given the tight credit market, debtors are motivated to present high EPS and low debt-to-equity ratios.

Beginning in the 1980s debtors have been using in-substance defeasance to obtain similar benefits. In-substance defeasance of debt is used where defeasance of debt is not included as an option in the debt instrument. The creditor is not forewarned that the debtor might transfer the debt with assets adequate to meet the debt obligation to a trust and, thereby, claim the debt is extinguished. Also, the creditor need not be informed when the debt is in-substance defeased.

The financial community has enthusiastically embraced this technique. Some companies have gone so far as to create debt with the intention of immediately employing in-substance defeasance; i.e., "instantaneous defeasance" to obtain the benefits of defeasance.

Exxon Corporation in 1982 eliminated $\$ 515$ million of debt from its balance sheet and posted a $\$ 132$ million profit by buying high-yield treasury securities and placing them in a trust to retire low-interest debt (15). Following Exxon, American Hospital Supply Corporation issued zero-coupon Eurobonds at $11.56 \%$ which it matched with a purchase of "stripped" U.S. Treasury bonds yielding $12.25 \%$. New debt of $\$ 2$ million was buried in the balance sheet of their unconsolidated subsidiary American Hospital Supply Finance Corporation (21). 
Lazard Realty, Inc. in 1984 used in-substance defeasance to unlock equity in 11,000 garden apartments purchased in 1979. Second mortgage rates were too high to use for refinancing. So Lazard bought $\$ 74$ million (maturity value) in government securities for $\$ 62$ million (current value), and placed them in an irrevocable trust to repay a preexisting $\$ 74$ million debt. It thus reported a $\$ 12$ million gain in the income statement (13).

The FASB banned the use of instantaneous defeasance as of September 1984 (8). James C. Treadway Jr., an SEC commissioner, said: "I am strongly opposed to instantaneous defeasance" and called it "a distortion of accounting principles" (1). But even when not instantaneous, in-substance defeasance is controversial. Roman L. Weil, director or the Institute of Professional Accounting, stated that in-substance defeasance (which he calls "de facto" defeasance) presents "managers with the opportunity to boost reported earnings, lower the debt-equity ratio and (in some cases) increase their own compensation" (20). Representative John D. Dingell, Democrat from Michigan, criticized the SEC for not taking "a stronger stand" against in-substance defeasance, "which its critics claim allow companies to create instant profits" (3). John Evans, a retired SEC commissioner said "I'm queasy about it [in-substance defeasance] because the debt is still legally debt, and the creation of earnings appears to be a charade" (2). In-substance defeasance is viewed by some as "an accounting device companies use to wipe long-term debt off their books" (17). Companies are accused of having "concoctcd so many ways to hide or disguise borrowings that deciphering their true liabilities is often impossible. Sometimes, debt isn't acknowledged anywhere; at other times, it's there, but finding it would take a financial wizard with hours of free time and a computer" (4). In-substance defeasance was referred to as the "equivalent of vanishing debt" by Forbes, which criticized the process because "a borrower can retire debt at a discount, and companies are allowed to show the discount as earnings" (14). In spite of these criticisms the FASB approved the use of in-substance defeasance within the parameters set in SFAS 76.

This article illustrates how to achieve profits and avoid losses in implementing SFAS 76. The parameters surrounding in-substance defeasance per SFAS 76 are discussed, and options regarding the types of trusts with tax implications of each type are also presented.

\section{In-Substance Defeasance Defined}

In-substance defeasance of debt is extinguishment of debt, as specifically addressed by the SFAS No. 76 Extinguishment of Debt (10). But legally the debt still exists. SFAS 76 subordinates the form of the contractual debtor/ creditor relationship to its substance but mandates specific action to achieve in-substance defeasance as follows:

The debtor irrevocably places cash or other assets in a trust to be used solely for satisfying scheduled payments of both interest 
and principal of a specific obligation and the possibility that the debtor will be required to make future payments with respect to that debt is remote. In this circumstance, debt is extinguished even though the debtor is not legally released from being the primary obligor under the debt obligation (10, para. 3).

The FASB has placed the following specific restrictions on trust assets used for in-substance defeasance:

The trust shall be restricted to owning only monetary assets that are essentially risk free to the amount, timing, and collection of interest and principal. The monetary assets shall be denominated in the currency in which the debt is payable. For debt denominated in U.S. dollars, essentially risk-free monetary assets shall be limited to any combination of the following:

(1) direct obligations of the U.S. government,

(2) obligations guaranteed by the U.S. government, and

(3) securities that are backed by U.S. government obligations as collateral under an arrangement by which the interest and principal payments on the collateral generally flow immediately through to the holder of the security.

However, some securities described in the previous sentence can be paid prior to scheduled maturity and so are not essentially risk free as to the timing of the colle stion of interest and principal; thus, they do not qualify for ownership by the trust (10, para. 4$)$.

Securities which are callable or convertible cannot be used for insubstance defeasance unless the callable/convertible options are cancelled. Costs of placing assets in the trust are taken into account as follows:

The monetary assets held by the trust shall provide cash flows (from interest and maturity of those assets) that approximately coincide, as to timing and amount, with scheduled interest and principal payments on the debt that is being extinguished.... If, in conjunction with placing assets in trust to effect an extinguishment of debt, it is expected that trust assets will be used to pay related costs, such as trustee fees, as well as to satisfy scheduled interest and principal payments of a specific debt, those costs shall be considered in determining the amount of funds required by the trust. On the other hand, if the debtor incurs an obligation to pay any related costs, the debtor shall accrue a liability for those probable future payments in the period that the debt is recognized as extinguished $(10$, paras. 4,5$)$. 


\section{In-Substance Defeasance Illustrated}

In-substance defeasance is allowed when applied to previously outstanding debt, but not to debt issued in contemplation of in-substance defeasance (i.e., instantaneous defeasance). The FASB technical bulletin on insubstance defeasance warns against placing assets in an irrevocable trust about the same time as debt is incurred. Corporate directors should take care to either state in the minutes that newly authorized debt is not being issued in contemplation of in-substance defeasance or make no statement on the issue. The Directors could currently authorize the issuance of debt, which in the future would qualify for in-substance defeasance so long as it was not issued with that intention. Violating the generally accepted accounting standard as mandated in SFAS 76 and its technical bulletin might result in an adverse audit opinion or public disapproval by the SEC.

The following examples illustrate the possible benefits of in-substance defeasance when one stays within the restrictions set by SFAS 76. Assume it is now June 30,1986, and the company wishes to in-substance defease an outstanding debt of six hundred, $\$ 1,000$ maturity value, $18 \%$ bonds issued at par to mature June 30, 2012. They purchase U.S. Government securities paying $12 \%$ annual interest, which will provide cashflow adequate to meet the bond interest and principal payments plus costs of establishing and maintaining a trust to manage both the U.S. securities and the company debt. The trustee takes physical possession of the U.S. securities and supporting debt documentation necessary to make and record the interest and final principal payments and keeps a separate set of financial records regarding management of the assets and debt. Depending on the type of trust established, the trust may be liable for tax on the asset income. The unrealized loss resulting from the above example amounts to $\$ 430,359$ and must be reported in the income statement but not the balance sheet. See Table 1 for detailed calculation of the loss and recommended journal entry.

TABLE 1

CALCULATION OF IN-SUBSTANCE DEFEASANCE LOSS

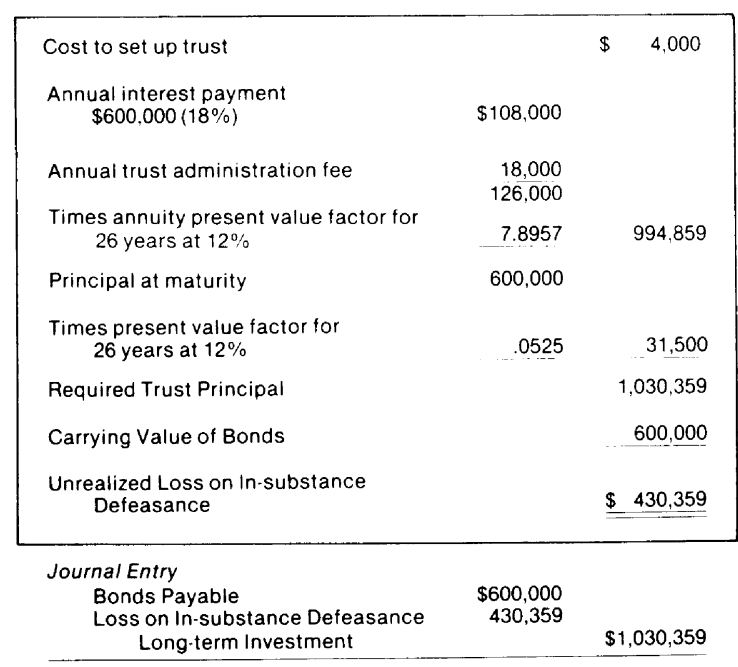


To show a gain one needs a lower interest rate on the outstanding debt, a higher interest rate on the trust assets or both. Using the assumptions above and in Table 1 except for the bonds being originally issued at $6 \%$ instead of $18 \%$ results in a gain of $\$ 232,881$. The calculation and its recommended journal entry are shown in Table 2.

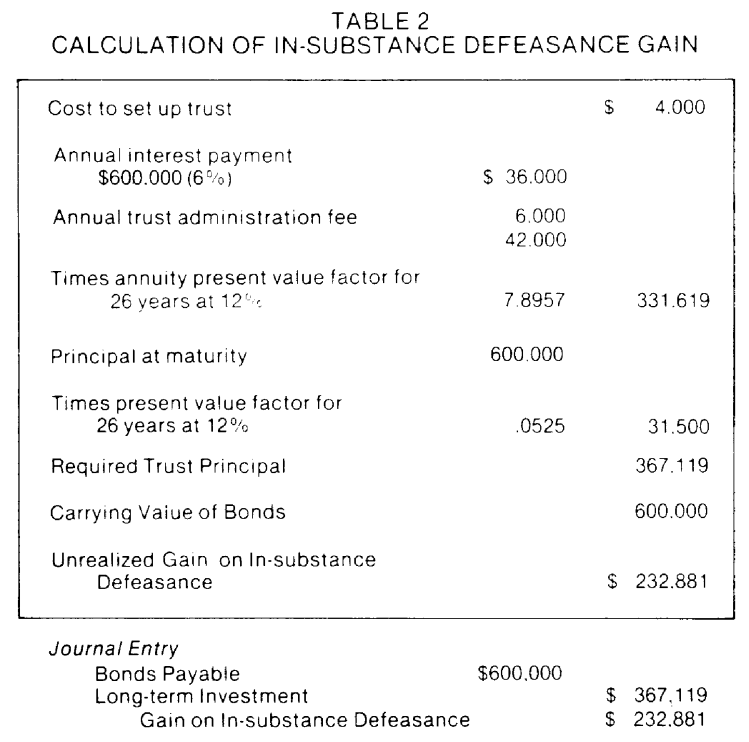

The equation to determine when the breakeven point $(\mathrm{BE})$ occurs is as follows:

$$
\begin{aligned}
& \mathrm{RTP}=\mathrm{a}+\left[\frac{\mathrm{F}_{\mathrm{n}}}{(1+\mathrm{r})^{n}}\right]+\left[\mathrm{F}_{\mathrm{n}}(\mathrm{b})+\mathrm{nc}\right] \times\left[\frac{1}{\mathrm{r}}\left(1-\frac{1}{(1+\mathrm{r})^{\mathrm{n}}}\right)\right](1) \\
& \text { where RTP }=\text { the initially required trust principal } \\
& \mathrm{a}=\text { initial setup costs of trust, } \\
& \mathrm{b}=\text { stated interest rate on debt based on an annual rate, } \\
& \mathrm{c}=\text { annual trust administration fees, } \\
& F_{n}=\text { maturity value of debt, } \\
& \mathrm{n}=\text { life of debt (and trust) in years, and } \\
& r=\text { effective annual interest rate on trust assets }
\end{aligned}
$$

BE occurs when RTP $=F_{n}$. If RTP $>F_{n}$ a loss is recognized and when $R T P<$ $F_{n}$ a gain is recognized. To find the effective interest rate at the breakeven point, RTP is set equal to $F_{n}$ and equation 1 is rearranged to:

$$
\mathrm{r}=\left[\frac{\mathrm{ar}}{\mathrm{F}_{\mathrm{n}}}\right]+\left[\frac{\mathrm{r}}{(1+\mathrm{r})^{\mathrm{n}}}\right]+\left[\mathrm{b}+\frac{\mathrm{nc}}{\overline{F_{n}}}\right] \times\left[1-\frac{1}{(1+\mathrm{r})^{\mathrm{n}}}\right](2)
$$

In deriving equations (1) and (2) it is assumed that: (a) all money values are in the same units, e.g., dollars; (b) interest payments are made annually, and 
the principal is paid at maturity; (c) trust assets earn a constant annual return; and (d) the debt was issued at par. If the debt was issued at a discount or premium, BE and the gain or loss is determined by comparing RTP to the carrying value of the debt (CVD) rather than $F_{n}$. Equation (1) may be used to calculate whether the desired gain can be attained. An iterative process is used in equation (2) to determine an effective annual interest rate to break even.

By way of example consider the case where:

$$
\begin{array}{ll}
\mathrm{RTP}=\mathrm{F}_{\mathrm{n}} & =\$ 1,000,000 \\
\mathrm{a} & =\$ 10,000, \\
\mathrm{~b} & =0.1, \\
\mathrm{c} & =\$ 10,000(1 \% \text { of initial assets }), \text { and } \\
\mathrm{n} & =10 \text { years }
\end{array}
$$

The authors first guess a value of $\mathrm{r}_{0}$ of $0.15(15 \%)$ and in three iterations obtained the following results:

$\begin{array}{ccc}\text { r (left side) } & \text { r (right side) } & \text { difference } \\ 0.189 & 0.150 & 0.039 \\ 0.200 & 0.189 & 0.011 \\ 0.202 & 0.200 & 0.002 \\ 0.202 & 0.202 & 0.000\end{array}$

Thus the trust would have to earn $20.2 \%$ per year to break even on a debt with an interest rate of only $10 \%$. Equations (1) and (2) may be appropriately modified when the principal is repaid as an annuity rather than as a lump sum at maturity.

The EPS increase from in-substance defeasance results when the cost of the debt is less than the return on the trust assets. Overall interest rates must substantially increase for risk-free assets, like federal treasury instruments, to have a greater yield than typical company debt. In efficient capital markets bond prices should decrease in recognition of the higher interest rates, enabling a possible gain on the in-substance defeasance. This single period EPS increase improves the debt-to-equity ratio and other indicators of performance and strength for the current period, and the improvement will extend into future periods.

In addition to careful consideration of the factors summarized in equation (2), a debt manager must establish the in-substance defeasance trust within particular parameters. To assist in this effort the general aspects of trusts are presented followed by specific characteristics of trusts applicable to insubstance defeasance.

\section{General Aspects of Trusts}

All trusts may be categorizes as implied, constructive, or express $(5,16)$. 
Figure I summarizes the three basic trust types. An implied trust arises by operation of law when a party who intends to create a trust fails to completely manifest that intent. The court will usually decree that a trust exists in favor of the intended beneficiary or where the intended beneficiary cannot be ascertained then in favor of the creator. This is known as a resulting trust. If the court did not furnish a recipient for the trust assets, the trustee might be able to retain the benefits against the settlor's (debtor's) wishes since the former holds legal title to the trust property. A constructive trust is created by law to remedy a wrong. For example, if one party fraudulently obtains property from another, the court can order the wrongdoer to hold the property in trust for the former owner.

\begin{tabular}{|lll|}
\multicolumn{2}{c}{ FIGURE 1 } \\
\hline BASIC TRUST TYPES \\
\hline $\begin{array}{l}\text { Intended and } \\
\text { completely } \\
\text { stated }\end{array}$ & $\begin{array}{l}\text { Intended but either } \\
\text { not stated at all or } \\
\text { not completely stated }\end{array}$ & $\begin{array}{l}\text { Not intended, imposed } \\
\text { by Courts to prevent } \\
\text { injustice }\end{array}$ \\
$\begin{array}{l}\text { Applicable to } \\
\text { in-substance } \\
\text { defeasance }\end{array}$ & $\begin{array}{l}\text { May be applicable to } \\
\text { in-substance defeas- } \\
\text { ance where an express } \\
\text { trust fails to name a } \\
\text { remainder beneficiary }\end{array}$ & $\begin{array}{l}\text { Not applicable to } \\
\text { in-substance } \\
\text { defeasance }\end{array}$ \\
\hline
\end{tabular}

Express trusts, that is, those intentionally created for a valid purpose are applicable and are discussed next. A resulting in-substance defeasance trust could arise where the creator of an express trust neglects to name a recipient of assets remaining after satisfaction of the debt. SFAS 76 mandates against return of assets to the settlor (debtor), so a remainder beneficiary is required. Attention should also be made to naming a trustee and providing for successor trustees since without a trustee, the trust could fail.

\section{Characteristics of In-Substance Defeasance Trusts}

Express trusts may be classified in different ways including: (a) intervivos vs. testamentary; (b) revocable vs. irrevocable; (c) simple vs. complex; and (d) grantor vs. nongrantor. An intervivos trust becomes effective while the settlor is alive, whereas a testamentary trust is part of a will and becomes effective on the settlor's death. Testamentary trusts cannot be created by corporations since property transfers which occur when a corporation terminates are treated differently than when an individual dies.

Trusts may be expressly made revocable or irrevocable. A revocable trust allows the settlor to effectively retain control of the assets. However, an in-substance defeasance trust must be irrevocable per SFAS 76.

A simple trust by its terms distributes current income only, must distribute all its current income, and has no charitable beneficiaries. If the trust accumulates income or distributes part or all of its corpus, it is complex. 
Many trusts are simple in some years and complex in others. Any trust not dry when it terminates is complex in the year of termination because it will distribute something other than current income. Under SFAS 76, the trust can be simple or complex or both in different years depending on how the debt is structured. In years when the scheduled repayment of debt requires payment only of interest (and administrative expenses and/or taxes) until some maturity date, and the current income matches the interest payment, (and administrative expenses and/or taxes) the trust is simple. However, for a company to show a gain on the balance sheet, it is expected that the annual income on the trust would be greater than the interest to be paid on the debt and associated expenses. Hence, income would accumulate until maturity when the debt is retired, and the trust would be complex in every year. There should be no unusual consequences to the defeasance aspects whether the trust is simple of complex in any given year. Figure II summarizes the requirements for a trust used to in-substance defease debt.

FIGURE ॥

IN-SUBSTANCE DEFEASANCE TRUST REQUIREMENTS

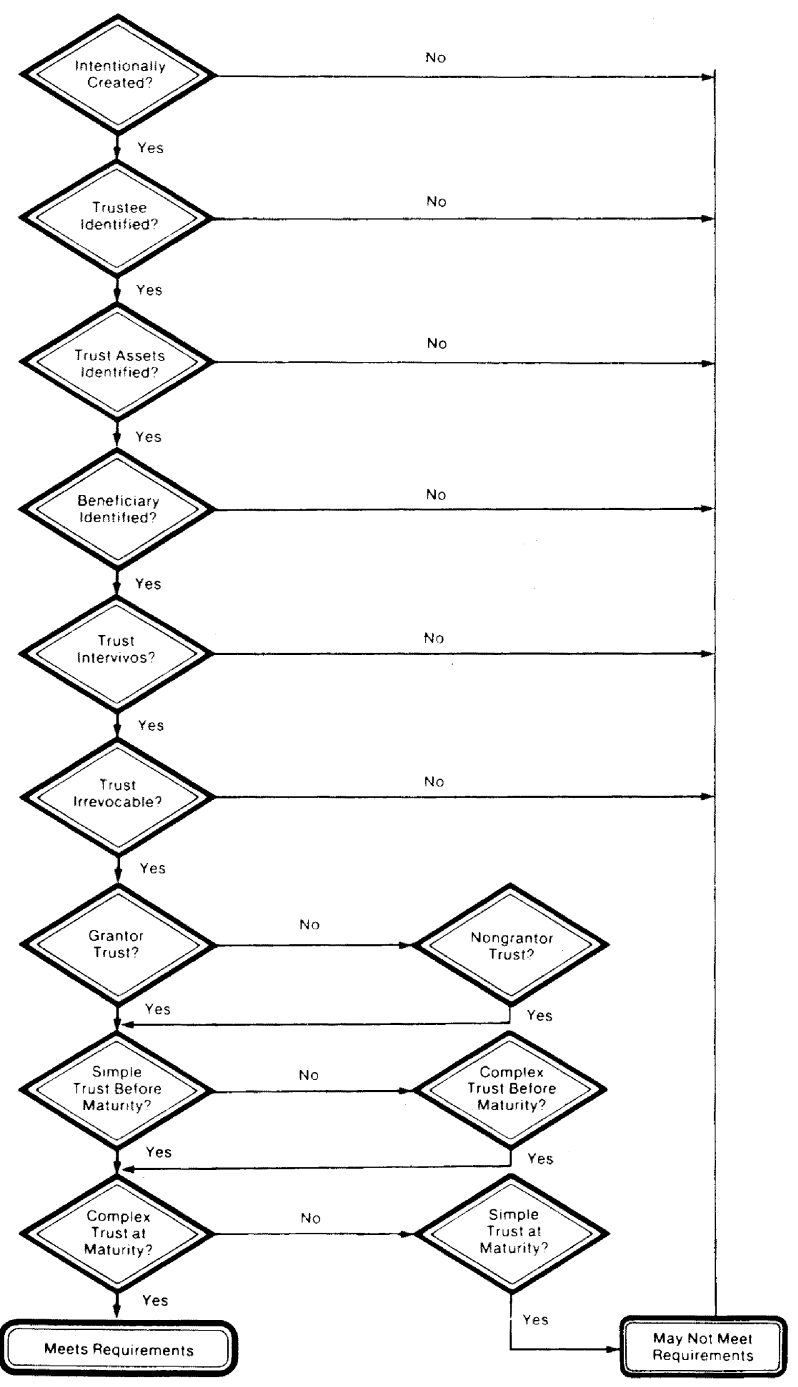




\section{Tax Aspects of the Trust Selected}

Normally a trust constitutes a separate entity. However, under the grantor trust provisions of the Internal Revenue Code (IRC) the settlor (or another person) may be treated as owner of some or all of the assets and accordingly taxed on some or all the trust income (12, sections 671-679).

Sections $671,673,678$, and 679 of the IRC might be applicable to whether grantor status obtains under the SFAS 76 parameters. To avoid grantor status under Section 671, the debtor should take care not to assign only future income to the trust but might, for instance, assign a series of bonds.

Section 673 provides that a settlor will be treated as the owner of any portion of a trust in which either the trust principal or income may reasonably be expected to revert to the settlor within ten years after the date of transfer. Since SFAS 76 will not allow reinvestment of income, a remainder will probably result which could revert to the settlor under the resulting trust doctrine. The settlor can avoid grantor status by designating a remainderman for any surplus. The remainderman should be given no power to control disposition of any remainder to avoid taxation under Section 678. No conflict with SFAS 76 should arise in naming a beneficiary of assets remaining at the debt's maturity. If the trustee is named as remainder beneficiary, any surplus might be deductible to the debtor as a reasonable cost of doing business under IRC Section 162(a). If a charity were to receive the remainder then because of the SFAS 76 requirement of structuring the payouts to coincide closely with the required payments, no charitable deduction would be allowed. To obtain a charitable deduction there must be more certainty to the payout as under a Charitable Remainder Annuity Trust, a Charitable Remainder Unitrust, or a Pooled Income Fund (12, section 664(d)(1), section 664(d)(2), and section 642(c)(5).

Grantor status under IRC Section 679 can be avoided by using a U.S. trust. For foreign trusts, grantor status may still be avoided in certain cases such as where the beneficiary is not a U.S. citizen either actually or constructively.

Initially, the FASB appeared to view the trust as a separate taxable entity from the debtor. In paragraph 5 of their Revised Exposure Draft the FASB included "taxes on trust income" as an example of "costs expected to be paid by the trust" (9). In response to this view Touche Ross \& Co. stated the following:

Paragraph 5 refers to providing, at the outset, for "taxes on trust income." Ordinarily, such trusts are grantor trusts and the federal income tax consequences thereof are included in the grantor corporation's tax return. Because the trust itself is rarely a taxable entity for federal purposes, we suggest some elucidation what the Board intended... (18)? 
In determining the amount of investment assets needed to defease a set amount of company debt, should the matching of fund inflows and outflows be done on a pretax or after-tax basis? Does the placement of investment assets in a grantor trust (which does not have a tax existence separate from the sponsoring company) or a trust that stands alone for tax purposes have a bearing on this? We believe that the matching of fund flows should be done on a pretax basis regardless of the type of trust involved (7).

These issues raised by Touche Ross \& Co. and Dart \& Kraft will be explored next.

Although Touche Ross and Co. stated that "[o]rdinarily such trusts are grantor trusts" (18), there is no such requirement in SFAS 76 and no reason in principle they must be. In fact, satisfaction of the SFAS 76 requirement of making remote the possibility that the debtor would have to make further payments may mandate selection of an independent trustee. An independent trustee might lessen chances of mismanagement (intentional or negligent) by the debtor and lower the chances that the debtor would be required to make further payments. An independent trustee by itself will not guarantee nongrantor status to the debtor but is one step in that direction. Since selection of the trustee can affect not only the grantor status of the trust but also the remoteness criteria of SFAS 76 it should be given due consideration.

The reason for the statement by Dart \& Kraft, that "[w]e believe that the matching of fund flows should be done on a pretax basis" is not clear. First, consider a grantor trust. The income tax consequences inure to the debtor, and the trustee need not be concerned with them. Calculation of the trust assets needed is relatively easy because one needs only to know the administration and setup fees and the presumably fixed interest rate on the investment. Also there is no change in grantor status or tax consequences if for some remote reason the trust becomes dry before the debt is satisfied, or the trust terminates with assets remaining. In the former case, the settlor can simply add assets and in the latter case any surplus would go to the named recipient. To place the assets in a grantor trust on an after-tax basis might diminish the possibility that an occurrence such as bankruptcy of the debtor leaves the debt unsatisfied. But bankruptcy taken by the debtor, in and of itself should not lessen the remoteness of the debtor having to make further payment since the bankruptcy would very like discharge the debt. At the same time, matching of fund flows on an after-tax basis would require the grantor to predict personal future tax consequences for a number of years, a feat that seems extraordinarily difficult if not impossible. An occurrence such as bankruptcy taken by the debtor would have the same effect as on a pretax basis.

Calculation of the amount of assets needed in a nongrantor trust on a 
pretax basis would be the same as for a grantor trust. But in the former situation the debtor would be required to make annual contributions for taxes based on the trust as a taxable entity and the trust language should provide for these annual contributions. Bankruptcy taken by the debtor in and of itself should not adversely affect the remoteness of the debtor having to make additional payments since again the debt would probably be discharged. To maintain nongrantor status where an excess remains after the debt is paid, the trust should name an appropriate remainder beneficiary. However, if the trust becomes dry before the debt is paid the nongrantor status should not be affected but the trust language should deal with additional payments by the debtor.

For nongrantor trusts on an after-tax basis it should also be feasible to calculate the amount of initial assets required, assuming tax laws and rates remain constant over the life of the trust. On that basis the amount required for tax payments by the trustee could be calculated with certainty. If tax law changes occur, the trust language should take into account possible contributions by the debtor and disposition of any remainder. Care would have to be taken not to change the nongrantor status of the trust. Again, bankruptcy should not have any effect on the remoteness of future payments for the same reasons stated above.

Thus for a grantor trust in an after-tax situation the difficulty of calculating tax consequences clearly points to placing assets on a pretax basis. For a nongrantor trust the reason is not so compelling and the debtor could reasonably place the assets in trust on a pre or after-tax basis.

\section{Additional Considerations}

Express trusts may use a provision to avoid the often time consuming and expensive judicial approval of the trustee's accounting. But SFAS 76 parameters allow creation of a trust without the creditor-beneficiary's knowledge, while requiring the possibility of the debtor having to make future payments be remote. It might be wise in this or perhaps in all situations, for a court to approve the accounting to satisfy the requirement that the possibility of further payment be remote. Without court approval, mismanagement (intentional or negligent) may be more probable, thereby increasing the probability that further payments are required. If court approval is not obtained, then at a minimum the trustees should be independent of the debtor even though in principle one person could serve as both.

The SFAS 76 requirement of assets being irrevocably placed in trust solely for satisfaction of the debt is easily accomplished in theory by basic drafting of the trust instrument. However, are the assets really irrevocably placed in trust? No clear answer exists where the trust is created as a fraud on other creditors or the debtor files for bankruptcy after creation? In the former situation the defrauded creditors can file a creditor's suit in equity to obtain the trust assets (6). In the latter situation the trustee in bankruptcy may be able to obtain the trust assets if the debtor created a preference for one 
creditor over other creditors (19, section 547) or committed fraud under the Bankruptcy Act (19, section 548). The independent trustee could evaluate the likelihood of fraud or bankruptcy rather than have the debtor make that judgment.

The SFAS 76 requirement that the possibility of further payment by the debtor be remote leaves open a similar question of who makes that determination (11). Since the technique can be very attractive to the debtor while having a potential for misleading unsophisticated investors, it is again suggested that someone independent of the debtor make the decision. The use of an independent person to judge both the remoteness of the debtor having to make future payments and the good faith of the debtor might quash some of the criticism leveled at in-substance defeasance.

\section{Summary and Conclusion}

Defeasance of debt has been a useful and recognized technique for many years. In-substance defeasance, a controversial new technique has been enthusiastically embraced by the financial community but approved by the FASB only within certain limitations. The FASB has banned the technique if it constitutes instantaneous in-substance defeasance defeasance. One primary purpose of using in-substance defeasance is to recognize an unrealized gain on the income statement and remove debt from the balance sheet, thereby enhancing a company's debt to equity ratio.

This article has provided guidelines for using in-substance defeasance within the parameters set by the FASB. Two equations are presented to show when a gain or loss occurs and the interest rate needed to breakeven for the case where income on the assets in an in-substance defeasance trust is used to service the debt and the corpus remaining at the debt's maturity is used to retire the debt principal.

Characteristics of trusts appropriate for in-substance defeasance are examined and presented in Figure II. They may be structured as grantor or nongrantor trusts depending whether the debtor wishes to incur the income tax consequences depending primarily on the relative tax brackets of the debtor and the trust. The authors suggest that for grantor trusts the assets be placed in the trust on a pretax basis; for nongrantor trusts a pretax or after-tax basis may be used.

It is the debtor who decides whether the in-substance defeasance trust is within the SFAS 76 parameters. Since the technique offers the debtor significant benefits while at the same time may be misleading to all but the most sophisticated investors, the authors suggest that someone independent of the debtor decide whether SFAS 76 requirements are being met in order to quash some of the criticisms of in-substance defeasance.

\section{References}

1. Berton, Lee and Ann Monroe. "FASB Mulls Ban on Defeasance 
Method Which Firms Issue Debt to Post Gains," Wall Street Journal, September 12, 1984, p. 6.

2. Berton, Lee. "FASB Adopts, 4-3, Controversial Method That Critics Assert Allows 'Instant' Profit." Wall Street Journal, November 30, 1983, p. 7.

3. _ "House Unit Probing SEC's Monitoring of Accounting Rules," Wall Street Journal, January 31, 1984, p. 56.

4. __ "Loose Ledgers: Many Firms Hide Debt to Give Them an Aura of Financial Strength," Wall Street Journal, December 13, 1983, p. 1.

5. Bogert, G.G. and G.T. Bogert, Trusts and Trustees, $2 \mathrm{~d}$ ed revised (St. Paul, Minn.: West Publ. Co., 1984), section 1.

6. Creditor's Rights and Remedies, (Portland, Oregon: Oregon State Bar, C.L.E., 1978), section 9.1.

7. Dart \& Kraft Comment Letter to the FASB Regarding Exposure Draft (Revised), Extinguishment of Debt, October 13, 1983.

8. "FASB Acts to Ban Use of Defeasance Applied to New Debt," Wall Street Journal, September 13, 1984, p. 4.

9. Financial Accounting Standards Board, Exposure Draft (Revised), Extinguishment of Debt, Stamford, Co.: FASB, 1983.

10. Financial Accounting Standards Board, Statement of Financial Accounting Standards No. 76, Extinguishment of Debt, Stamford, Conn.: FASB, 1983.

11. Financial Accounting Standards Board, Technical Bulletin 84-4 Oct. 17, 1984 p. 4.

12. Internal Revenue Code.

13. "Investor Takes Cue From Corporations," Wall Street Journal, May 22, 1985 p. 37.

14. Konrad, Walecia. "Numbers Game: Reading Between the Pictures," Forbes, January 30, 1984, p. 126.

15. Peterson, Pamela, David Peterson and James Ang. "The Extinguishment of Debt Through In-Substance Defeasance," Financial Management, 14, 1 (Spring 1985), 59-67.

16. Schantz, W.T. Commercial Law for Business and Accounting Students: A Complete Business Law Text and CPA Law Review (St. Paul, Minn.: West Publ. Co., 1980), p. 1130.

17. "SEC Approves Rules On-Device to Keep Debt Off Balance Sheet," Wall Street Journal, December 23, 1983, p. 3.

18. Touche Ross \& Co., Comment Letter to FASB Regarding Exposure Draft (Revised), Extinguishment of Debt, September 12, 1983, p. 10.

19. United States Code ann., Title 11 Bankruptcy (1979 and West Supp. 1985).

20. Weil, Roman L. "De- or Misfeasance? A Look at the New FASB Ruling," Barron's, December 5, 1983, p. 50.

21. Weiss, Stuart. "The Accounting Watchdogs Have Been Outfoxed Again," Business Week, November 26, 1984, p. 168. 